\title{
Stunting and Household Food Expenditures between Junior High School Students from Smoker And Non-Smoker Families
}

\author{
Risky Malinda ${ }^{1}$, Etti Sudaryati $^{2}$, Evawany Aritonang ${ }^{3}$ \\ 1,2,3 Faculty of Public Health, Universitas Sumatera Utara, Medan, Indonesia \\ Email: riskymalinda95@gmail.com
}

\begin{abstract}
:
Stunting is a linear growth failure due to insufficient long-term nutritional intake. The higher the proportion of household expenditure from total income, the lower the economic level of the family so it is at risk of food insecurity. This study aims to determine the differences in the proportion of stunting and household food expenditure between students from smokers and non-smokers families. This study was an observational study with a cross sectional design with a sample of 98 students from smokers 'families and 98 students from nonsmokers' families. Stunting data is obtained by measuring student height. Household food expenditure is obtained by comparing the total household expenditure spent on food with the total income earned during income. This study uses statistical analysis using the chi-square test. There was a difference in the proportion of stunting $(p=<0.001)$ and the proportion of household food expenditure ( $p=<0.001)$ between smokers and non-smokers 'families where the proportion of stunting and household improvement was higher among smokers' families. The conclusion is there're differences in the proportion of stunting and household food expenditure in students from smoker families and non-smoker families. Families should limit cigarette consumption and allocate appropriately in household food expenditures.
\end{abstract}

Keywords:

stunting; household food expenditure; smoker

\section{Introduction}

Stunting is a failure of linear height growth due to inadequate long-term nutrition intake so that a person has a shorter body than others his age. Children are defined as stunted if their height for ages is more than two standard deviations below the median WHO Child Growth Standards. (WHO, 2019).

Stunting has long term effects on individuals and society that reduced physical and cognitive development, reduced productive capacity and poor health, and increased risk of degenerative diseases in adulthood (The state of the world's children, 2013).

World bank data (2017) shows the prevalence of stunting in toddlers worldwide is $22.2 \%$. Considerable prevalence is found in poor and developing countries. The prevalence of stunting in toddlers in Indonesia which is $30.8 \%$ shows a fairly high number compared to the prevalence of stunting in the world (Kemenkes, 2018). This figure is still classified as very high when compared with the prevalence of stunting in the world.

Stunting tends to be experienced by people with low economic and income levels. Income greatly determines the ability of families to provide sufficient and quality food for their children. The greater the proportion of household food expenditure from total income, the lower the economic level of the family so that the risk of experiencing food insecurity. (Deaton and Muellbauer, 1980).

Another thing that exacerbates family food security is smoking. According to WHO (2015), Indonesia is the first ranks and the highest compared to other countries with the 
highest number of active male smokers over 15 years in the world $(76.2 \%)$. Based on Riskesdas data (2018), the national prevalence of smokers over 10 years is $28.8 \%$. The prevalence of smokers in North Sumatra Province is also close to the national prevalence of almost $28 \%$. Deli Serdang District has a prevalence of $30.6 \%$, this figure is higher than the provincial capital city of Medan, which amounted to $28.8 \%$ (Kemenkes RI, 2013).

Most smokers in Indonesia are poor people who come from a low economy who have difficulty meeting their basic daily needs (Nasution, 2015). Based on Riskesdas (2010), the average family cigarette expenditure for a month is Rp. 153,179 to Rp. 200,815 with a percentage of $7.54 \%$ to $8.03 \%$ compared with total household expenditure.

Cigarette expenditure will reduce the allocation of household food expenditure that can be used to buy nutritious food for children such as one cigarette can be replaced with one egg that is sufficient to meet the child's nutrition. The presence of a smoker family member will put the family at risk of experiencing food insecurity. This condition causes children to tend to experience nutritional problems such as stunting.

The problem of stunting, which has only focused on toddlers and elementary school children, has turned out to be able to continue until junior high school children. Based on Riskesdas data (2013) the prevalence of stunted adolescents in Indonesia aged 13 to 15 years is $35.1 \%$ (13.8\% is moderate stunted and $21.3 \%$ is severe stunted). North Sumatra Province itself has a stunting prevalence in adolescents greater than the national stunting prevalence of $40.4 \%$.

\section{Research Method}

This study was an observational study using a cross sectional design. This research was conducted at a junior high school in Deli Serdang Regency. The population in this study were all junior high school students who came from smokers and nonsmokers' families. Sample was carried out by multistage random sampling technique. Sample size was obtained using a sample size formula for two population proportions. The number of samples is 98 students from smokers 'families and 98 students from nonsmokers' families. Sampling of students is done randomly by simple random sampling method.

The stunting data obtained through measurements of students' height using a microtoise and the results were processed using the WHO Anthro Plus program to obtain a height $z$-score according to age adjusted for gender. The measurement categories are stunting (z-score TB / U <-2 SD) and normal (z-score TB / U $\geq-2$ SD) (WHO, 2007).

Data on the proportion of family food expenditure is obtained by comparing the total household expenditure spent on food with the total income earned during a month. The proportion categories of family food expenditure are low food expenditure $<50 \%$ and high food expenditure $\geq 50 \%$ (Smith and Subandoro, 2007).

The analysis uses the chi-square test to find out whether there are differences in the proportion of stunting and household food expenditure between students from smokers and non-smokers' families with a value of $\alpha=0.05$.

\section{Result and Discussion}

The study was conducted on 196 junior high school students in Deli Serdang Regency. The results include a description of students' characteristics, differences in the incidence of stunting, and the proportion of food expenditure in smokers and nonsmokers' families. The 
Britain International of Humanties and Social Sciences (BIoHS) Journal

ISSN: 2685-3868(Online), 2685-1989(Print)

Vol. 2, No. 1, February 2020, Page: 308-313

characteristics of all student samples are presented in Table 1. below:

Table 1. Characteristic of Respondent

\begin{tabular}{|c|c|c|c|c|}
\hline \multirow[t]{2}{*}{ Characteristics } & \multicolumn{2}{|c|}{$\begin{array}{l}\text { Non Smoker } \\
\text { Families }\end{array}$} & \multicolumn{2}{|c|}{$\begin{array}{l}\text { Smoker } \\
\text { Families }\end{array}$} \\
\hline & $\mathrm{n}$ & $\%$ & $\mathrm{n}$ & $\%$ \\
\hline \multicolumn{5}{|l|}{ Gender } \\
\hline Boy & 36 & 36.8 & 53 & 54.1 \\
\hline Girl & 62 & 63.2 & 45 & 45.9 \\
\hline \multicolumn{5}{|l|}{ Age } \\
\hline 11 years old & 12 & 12.3 & 15 & 15.3 \\
\hline 12 years old & 44 & 44.9 & 40 & 40.8 \\
\hline 13 years old & 38 & 38.8 & 37 & 37.8 \\
\hline 14 years & 4 & 4.0 & 6 & 6.1 \\
\hline \multicolumn{5}{|l|}{ Father Education } \\
\hline Elementary school & 14 & 14.3 & 17 & 17.3 \\
\hline Junior high school & 20 & 20.5 & 32 & 32.7 \\
\hline Senior high school & 52 & 53.0 & 46 & 46.9 \\
\hline University & 12 & 12.2 & 3 & 3.1 \\
\hline \multicolumn{5}{|l|}{ Mother education } \\
\hline Elementary school & 15 & 15.3 & 15 & 15.3 \\
\hline Junior high school & 31 & 31.7 & 30 & 30.6 \\
\hline Senior high school & 45 & 45.9 & 49 & 50.0 \\
\hline University & 7 & 7.1 & 4 & 4.1 \\
\hline \multicolumn{5}{|l|}{ Father's occupation } \\
\hline Odd jobs & 2 & 2.0 & 7 & 7.2 \\
\hline $\begin{array}{l}\text { Laborers, Construction } \\
\text { workers, Driver }\end{array}$ & 21 & 21.4 & 35 & 35.7 \\
\hline Farmers & 5 & 5.1 & 11 & 11.2 \\
\hline Entrepreneur & 51 & 52.0 & 33 & 33.7 \\
\hline Private employees & 12 & 12.3 & 7 & 7.1 \\
\hline State Civil Apparatus & 7 & 7.2 & 5 & 5.1 \\
\hline \multicolumn{5}{|l|}{ Family Size } \\
\hline 1-4 people & 49 & 50.0 & 25 & 25.5 \\
\hline$>4$ & 49 & 50.0 & 73 & 74.5 \\
\hline
\end{tabular}

Students who come from smokers' families generally have fathers who are less educated than students from nonsmokers. Parents of smokers' families mostly work as unskilled laborers, namely odd workers, laborers, drivers and construction workers. Generally students from smokers' families have more than 4 family members who live and eat in the same kitchen.

The large number of family members who live and eat in the same kitchen is one of the things that affects the nutritional situation of family members. This is caused by the distribution of food which increases the chances of the less amount of food each family member receives and increases the risk of transmission of diseases due to overcrowding such as channel disease breathing and diarrhea that cause malnutrition (Yasmin, et al 2014). 


\subsection{The Difference in the Proportion of Stunting between Students from Smokers and Non-Smokers' Families}

The results of the different proportions test conducted to test the difference in the proportion of stunting between students from smokers and nonsmokers' families also showed a significant difference with the value $(\mathrm{p}=<0.001)$ which means that there were differences in the incidence of stunting in students from smokers' and non-smokers families

Table 2. Distribution of Frequency of Stunting Incidence in Students from Smokers and

\begin{tabular}{|c|c|c|c|c|c|}
\hline \multirow{2}{*}{$\begin{array}{l}\text { Nutritional status } \\
\text { Height for Age }\end{array}$} & \multicolumn{2}{|c|}{$\begin{array}{l}\text { Non Smoker } \\
\text { Families }\end{array}$} & \multicolumn{2}{|c|}{$\begin{array}{l}\text { Smoker } \\
\text { Families }\end{array}$} & \multirow[t]{2}{*}{ p-value } \\
\hline & $\mathrm{n}$ & $\%$ & $\mathrm{n}$ & $\%$ & \\
\hline Normal & 81 & 82.7 & 51 & 52.0 & \multirow{3}{*}{$<0.001$} \\
\hline stunting & 17 & 17.3 & 47 & 48.0 & \\
\hline Total & 98 & 100.0 & 98 & 100.0 & \\
\hline
\end{tabular}

The results of this study are in line with research conducted by Semba et al. (2006) showed that there were influences of smokers 'fathers with stunting in children (OR $=1.09$, 95\% CI 1.04-1.15, P <0.001), which means that children who come from smokers' fathers are 1.09 times more likely to be stunted than children coming from a father who is not a smoker. The relationship of fathers who smoke with stunting is also found in research Yasmin, et al. (2014) which mentions fathers who smoke are associated with the incidence of stunting in school-age children in Indonesia.

Households that have smokers' fathers are associated with an increased risk of stunting in children due to cigarette which has shifted the need for nutritious foods that are essential for children's growth and development (Onis, 2001). Cigarette consumption increases the risk of malnutrition in children because the allocation for cigarettes is more than to buy food (Bayer, et al., 2001).

\subsection{The Difference in the Household Food Expenditure between Students from Smokers and Non-Smokers' Families}

The results showed there were differences in the proportion of household food expenditure for students from smokers and nonsmokers' families $(\mathrm{p}=<0.001)$. The proportion of household food expenditure in smokers' families that has a high proportion of household food expenditure $(\geq 50 \%)$ is $79.6 \%$ percent. While the majority of non-smoker families have a low proportion of household food expenditure $(<50 \%)$ which is $60.2 \%$. These results indicate that smokers 'families have a higher proportion of household food expenditure compared to nonsmokers' families.

Table 3. Distribution of Proportions of Family Food Expenditures for Students from Smokers and Non-Smokers' Families

\begin{tabular}{|c|c|c|c|c|c|}
\hline \multirow{2}{*}{$\begin{array}{l}\text { Household Food } \\
\text { Expenditure }\end{array}$} & \multicolumn{2}{|c|}{$\begin{array}{l}\text { Non Smoker } \\
\text { Families }\end{array}$} & \multicolumn{2}{|c|}{$\begin{array}{l}\text { Smoker } \\
\text { Families }\end{array}$} & \multirow[t]{2}{*}{ p-value } \\
\hline & $\mathrm{n}$ & $\%$ & $\mathrm{n}$ & $\%$ & \\
\hline Low $(<50 \%)$ & 59 & 60.2 & 20 & 20.4 & \multirow{3}{*}{$<0.001$} \\
\hline High $(\geq 50 \%)$ & 39 & 39.8 & 78 & 79.6 & \\
\hline Total & 98 & 100.0 & 98 & 100.0 & \\
\hline
\end{tabular}


A high proportion of food expenditure is associated with a low economic level. The higher the proportion of food expenditure compared to the amount of income, the lower the economic level of the family so that it is prone to experience food vulnerability (Amalia dan Mahmudiono, 2017). This study shows that there is a significant difference in the proportion of household food expenditure for students from smokers and nonsmokers' families. in Deli Serdang District, it can be suggested that most smokers' families have a low economic level who are at risk of experiencing food insecurity.

WHO has presented three main ways tobacco has worsened poverty in Indonesia at the household level. First, tobacco spending takes over money that can be spent on basic needs. Second, smoking causes increased health care needs, lost productivity and premature death of wage earners. Third, those who work in tobacco-related work experience specifically low wages and high health risks (WHO, 2004).

Low economic status plus expenditure on cigarettes will worsen the condition of family food security because the costs that should be allocated to food but must be used for cigarette shopping. Side effects of tobacco use include increasing the risk of malnutrition in children from smokers' families. A large proportion of household income is diverted for cigarettes with a smaller proportion spent on food. (Semba, et al., 2010). Research in Bangladesh also shows poor families who have smokers' fathers so that most of the weekly income is spent on tobacco thereby diverting money that might be used for food (Efroymson, et al., 2001). Low economic conditions coupled with spending on cigarette shopping result in food insecurity and in the long run will lead to nutritional problems namely stunting.

\section{Conclusion}

This study found that there was a significant difference in the proportion of stunting and household food expenditure between junior high school students from smokers and nonsmokers families. The proportion of stunting and household food expenditure is higher in junior high school students who come from smokers' families. This is caused the majority of smokers are poor people who have high household food expenditure. Low economic status plus expenditure on cigarettes will worsen the condition of food security because the costs that should be allocated to food but must be used for cigarette. These conditions in the long run will lead to nutritional problems namely stunting.

Families should reduce or even stop smoking and allocate family income precisely for household food expenditure so that there is enough food available in quantity and quality to meet the nutritional needs of children.

\section{References}

Amalia, I.N. \& Mamudiono, T. 2017. Hubungan Pendapatan, Total Pengeluaran, Proporsi Pengeluaran Pangan dengan Status Ketahanan Rumah Tangga Petani Gurem.

Beyer, J., Lovelace, C., \& Yurekli. 2001. A.Poverty and Tobacco. Tob Control 10):210-211.

Deaton, A. and J. Muellbauer. 1980. Economics and Consumer Behavior. Cambridge University Press : London.

Efroymson D, Ahmed S, Townsend J, Alam SM, Dey AR, Saha R, et al. 2001. Hungry for tobacco: an analysis of the economic impact of tobacco consumption on the poor in Bangladesh.Tobacco Control 10: 212-7.

Kemenkes RI. 2010. Laporan Hasil Riset Kesehatan Dasar (Riskesdas) Nasional. 2010. Jakarta: 
Balitbang Kemenkes RI.

Kemenkes RI. (2013). Laporan Hasil Riset Kesehatan Dasar (Riskesdas) Provinsi Sumatera Utara. 2013. Jakarta: Balitbang Kemenkes RI..

Kemenkes RI. (2018). Laporan Hasil Riset Kesehatan Dasar (Riskesdas) Nasional 2018. Jakarta: Balitbang Kemenkes RI

Nasution, S.K., Sudaryati, E., Nasution, N. 2015. Gambaran dan Status Gizi dan Infeksi Saluran Penafasan Akut (ISPA) pada Anak Balita Keluarga Perokok di Desa Padang Bulan Kecamatan Kotanopan Kabupaten Mandailing Natal. Medan : Universitas Sumatere Utara.

Onis, M. 2001. Child Growth and Development. In: Semba RD, Bloem MW,eds. Nutrition and Health in Developing Countries. Totowa, NJ: Humana Press : 71-91.

Semba, R. D., Kalm, L.M., de Pess, S., Ricks, M. O., Sari, M \& Bloem, M.W. 2006. Paternal Smoking is Associated with Increased Risk Of Child Malnutrition Among Poor Urban Families in Indonesia. Public Health Nutrition: 10(1), 7-15

Smith, Lisa C. and Ali Subandoro. 2007. Measuring Food Security Using Household Expenditure Surveys. International Food Policy Reseacrh Institute. Washington D.C

The World Bank. 2017. Prevalence of stunting, height for age (\% of children under 5). https://data .worldbank.org/indicator/SH.STA.STNT.ZS?view=chart (accessed 10 October 2019).

The state of the world's children. 2013. Children with disabilities. New York: United Nations Children's Fund. http://www.unicef.org.uk/Documents/Publicati on-pdfs/sowc2013-children-with-disabilities.pdf, (accessed 21 October 2019).

WHO. 2004. Tobacco increases thepoverty of individuals and families. Tobacco Free Initiativ. Geneva: WHO. http://www.who.int/tobacco/ communications/events/wntd/2004/tobaccofacts_families/en/. (accessed 18 October 2019).

WHO. 2015. Prevalence of Tobbaco Smoking. http://gamapserver.who.int/gho/interactive_charts/tobacco/use/atlas.html (accessed 12 Februari 2019).

WHO.2019. Stunting in a nutshell. https://www. who.int/nutrition/healthygrowthproj_stunted_videos/en/. (accessed 12 Februari 2019).

Yasmin G, Kustiyah L, Dwiriani CM. 2014. Risk Factor of Stunting among School-Aged Children from Eight Provinces in Indonesia. Pakistan Journal of Nutrition. 2014. 13(10):557-566. 